\title{
Size structure of dense populations of the brittle star Ophiura sarsii (Ophiuroidea: Echinodermata) in the bathyal zone around Japan
}

\author{
Toshihiko Fujita, Suguru Ohta
}

Ocean Research Institute, University of Tokyo, Minamidai 1-15-1, Nakano-ku, Tokyo 164, Japan

\begin{abstract}
The epibenthic ophiuroid Ophiura sarsii forms widely distributed, dense beds in the upper bathyal zone around northern Japan. Population densities ranged from about 30 to several hundred ind. $\mathrm{m}^{-2}$. Size-frequency distributions were polymodal, and were usually dominated by a peak of large individuals which was probably composed of many year classes. Maximum size was found to increase with increasing depth in the area off $\bar{O}$ tsuchi, Pacific coast of northeastern Japan. Relatively strong recruitment was recognized in the shallower part of the dense bed, where $O$. sarsii predominated in the absence of other ophiuroid species. At greater depths, modes of small individuals were inconspicuous, and $O$. sarsii attained a larger maximum size. Comparisons of size structure at various localities showed that size was greatest at lower population densities, probably through density-dependent effects Consequently, biomass was relatively constant at the different localities.
\end{abstract}

\section{INTRODUCTION}

High-density populations have been reported for a number of species of brittle stars. In shallow waters, several species of epibenthic ophiuroids are known to form dense beds; Ophiothrix fragilis (Warner 1971) and Ophiocomina nigra (Wilson et al. 1977) are found in patchy dense aggregations. Another epibenthic ophiuroid, Ophiothrix oesterdii, also forms a dense bed in a predator-free salt water lake in the Bahamas (Aronson \& Harms 1985). In the bathyal zone too, many epibenthic ophiuroids are found at high density (Fujita \& Ohta 1989). According to Aronson \& Sues (1987), such dense beds of ophiuroids are found only where predation pressure is low and are more characteristic of deep than of coastal waters. Infaunal amphiurid ophiuroids which are less exposed to predators often form dense beds in shallow waters, e.g. Amphiura filiformis (Muus 1981), as well as in the deep sea (Ohta 1983, Fujita 1989).

A widely-distributed brittle star, Ophiura sarsï Lütken, forms a dense bed in the bathyal zone off $\bar{O}$ tsuchi, northeastern Japan (Fujita \& Ohta 1989). Photographic observations showed that, in contrast with the dense patches of the shallow-water gregarious species
(Ophiothrix fragilis and Ophiocomina nigra), O. sarsii uniformly covered large areas of the sea floor, with a regular spatial pattern. At a depth of about $280 \mathrm{~m}$ off Otsuchi, mean density of $O$. sarsii is $373 \mathrm{~m}^{-2}$ and covers $96 \%$ of the sea bottom; the remaining $4 \%$ is occupied by other organisms and their halo-like bare areas.

Although such dense beds are thought to be a common feature for ophiuroids, particularly in the bathyal zone, their ecology is as yet poorly understood. In order to clarify the ecological significance of these dense beds of ophiuroids, we focused in the present study on the population structure of Ophiura sarsii, this being considered one of the important characteristics required to elucidate the ecological nature of dense beds. Knowledge of age structure of the population can provide an understanding of how high-density populations of the ophiuroid are maintained. We examined the population structure of $O$. sarsi through analysis of size-frequency distributions. Seasonal variations in the size structures were estimated from a time-series sample off $\bar{O}$ tsuchi, and differences in the size structures were examined along the depth gradient. Regional comparison was made at isobathic (about $250 \mathrm{~m}$ ) stations at several other localities around Japan. 


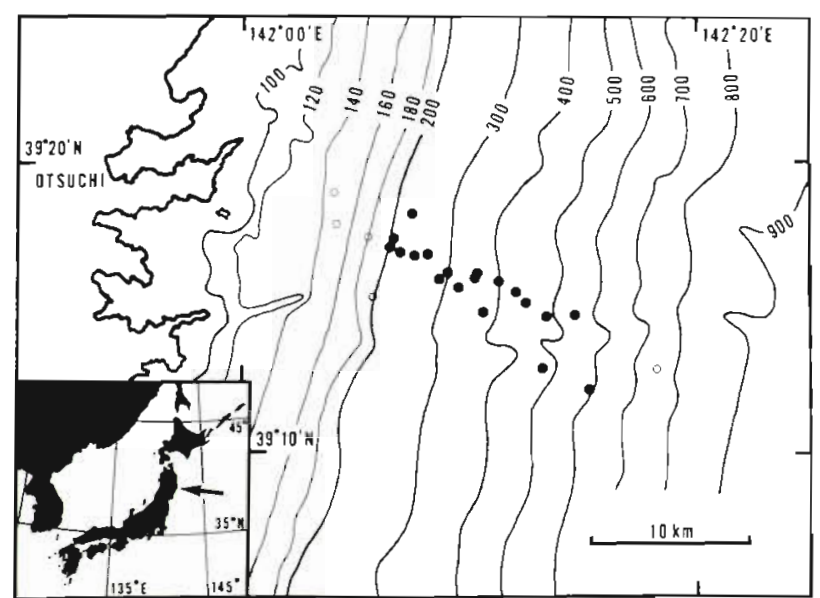

Fig. 1. Sampling stations off Otsuchi, northeastern Japan. Circles indicate photographic stations: $(\bullet)$ stations where dense beds of ophiuroids including Ophiura sarsii were found (O) stations where ophiuroids were sparse. Dense beds of $O$ sarsij were observed at depths from 200 to about $600 \mathrm{~m}$ (horizontal width ca $15 \mathrm{~km}$ ). Depth contours in $\mathrm{m}$

\section{MATERIALS AND METHODS}

Study area. Samples of Ophiura sarsii were collected from seas around Japan during 7 cruises of the RV 'Tansei Maru' and 2 cruises of the RV 'Hakuho Maru' of the Ocean Research Institute, University of Tokyo, from 1982 to 1989. Two additional samples were obtained from the RV 'Yayoi' of the Ōtsuchi Marine Research Center of the Ocean Research Institute. Epibenthic ophiuroids were numerically dominant in megabenthic assemblages at all stations studied. A bathymetric transect was established off Otsuchi, on the Pacific side of northeastern Japan, for investigations of the dense bed along the depth gradient (Fig. 1, Table 1). In this area, the bottom sediment was very fine sand. Bottom temperature was about 4.0 to $2.5^{\circ} \mathrm{C}$ between depths of 200 and $600 \mathrm{~m}$ and was almost constant throughout the year. At about $280 \mathrm{~m}$ depth, ophiuroids comprise $99 \%$ of the epifaunal megabenthic assemblage in terms of number of individuals, and other organisms are sparsely distributed, mainly including coelenterates, gastropods and anomuran crustaceans (Fujita \& Ohta 1989). Macrobenthic organisms and some environmental characteristics on this transect were described by Kojima \& Ohta (1989). A time-series sample of $O$. sarsiiwas collected at a fixed station at about $250 \mathrm{~m}$ depth off $\bar{O}$ tsuchi. Samples were also collected at about $250 \mathrm{~m}$ depth at 6 other localities around northern Japan for regional comparison of dense beds (Tables 1 and 2; see also Fig. 9). At these localities, the bottom sediment was mud and bottom temperature was $6.9^{\circ} \mathrm{C}$ at $\operatorname{Stn} 7$ and $1.6^{\circ} \mathrm{C}$ at Stn 8 and $1.2^{\circ} \mathrm{C}$ at Stn 13 , measured in October 1988 .
Size-frequency distribution. Size-frequency distributions of the Ophiura sarsii populations were examined from the samples collected by trawling and dredging. Four types of gear were used: a beam trawl with shrimp net of $3 \mathrm{~m}$ span, a Sigsby-Agassiz beam trawl of $2 \mathrm{~m}$ span, and 2 ORI-type biological dredges of 1 and $0.5 \mathrm{~m}$ span. Samples were fixed with neutral $10 \%$ seawater formalin and measurements of size and weight were carried out on the fixed specimens. In cases where the total number of individuals was too large, the sample was divided into subsamples of about a half to eighths and the subsamples examined. Body size of the ophiuroid was measured as the disc diameter on the aboral side. Measurements from the base of one arm to the opposite interradius was made using an eyepiece micrometer under a binocular microscope at a magnification of 8 to $40 \times$, or directly by means of vernier calipers. Most of the samples were collected by the nets of $5 \mathrm{~mm}$ mesh opening, and only 2 samples (Stns $\mathrm{S} 1$ and S2) were collected by the $1 \mathrm{~mm}$ mesh net which was attached to the ORI-type biological dredge of $0.5 \mathrm{~m}$ span. When the nets with mesh opening $5 \mathrm{~mm}$ were used, the number of individuals was underestimated if disc diameter was less than $2 \mathrm{~mm}$. We treated these assemblages of collected samples as populations; the term recruitment refers to the influx of new members into these parent populations.

On the assumption that size frequencies of age classes are normal distributions, any composite size-frequency data set can be resolved into its component Gaussian distributions. The component distributions were calculated by numerical methods minimizing the discrepancy between theoretical frequencies and the observed histogram through iterative algorithm. The method employed in the present investigation was the BASIC computer program described by Akamine (1982). Skewness of size-frequency distribution is one of the parameters estimating recruitment (Ebert 1983). Skewness was calculated as the third central moment divided by the cube of the standard deviation ( $g_{1}$ in Sokal \& Rohlf 1981).

Density and biomass. Density estimates were obtained by photographic analysis. Bottom photographs were taken using a tethered deep-sea stereo camera system, positioned about $2 \mathrm{~m}$ off the bottom. Between about 200 and 800 stereo pairs of black and white photographs were taken every $6 \mathrm{~s}$ during a period of about 20 to $80 \mathrm{~min}$ at each station. The ship drifted with the current and wind, and the camera moved about 0.5 to $7 \mathrm{~m}$ between exposures. The photographs were inspected in detail using a stereoscopic viewer. Area covered by bottom photographs was calculated by stereoscopic analysis. The total area covered at each station ranged from about 200 to $3000 \mathrm{~m}^{2}$. It is difficult to discriminate precisely the ophiuroid species from one another on the photographs, and the density of ophiuroids was estimated for all epibenthic species 





observed on the photographs. Species composition of ophiuroids was examined based on the samples collected by trawling. The minimum size of ophiuroids clearly recognized in photographs was about $2 \mathrm{~mm}$ disc diameter, which was approximately equivalent to the minimum size of specimens collected by the beam trawls of $5 \mathrm{~mm}$ mesh opening. The details of the camera system, its operation and the method of stereoscopic analysis of the photographs were described in Ohta $(1976,1983)$.

Wet-weight biomass was calculated from the density value (estimated by photographs) and the size-frequency distribution (measured by trawled specimens) at each station. Conversion was made by means of a size/ wet weight regression obtained from measurements of trawled specimens (Fujita \& Ohta 1989; W $=0.00065$ $D^{2.8}, r=1.00, N=32$; where $W$ is wet weight in $g$ and $D$ is disc diameter in $\mathrm{mm}$ ). At each station, total wet weight of all individuals in the size frequency was calculated using this formula, and this total weight was converted into the biomass per unit area by the density estimate.

\section{RESULTS}

\section{General characteristics of size structure}

The size-frequency distributions of Ophiura sarsii off Ōtsuchi and in the other studied areas are shown in Figs. 2, 3, 6 and 9. Two or more modes were usually found in the frequency histograms indicating an underlying polymodality. This implies more or less discrete recruitment. The size distributions included a conspicuous mode of large individuals with a thin left-hand tail of small individuals showing negative skewness. Fig. 2 offers an example of the frequency histogram based on

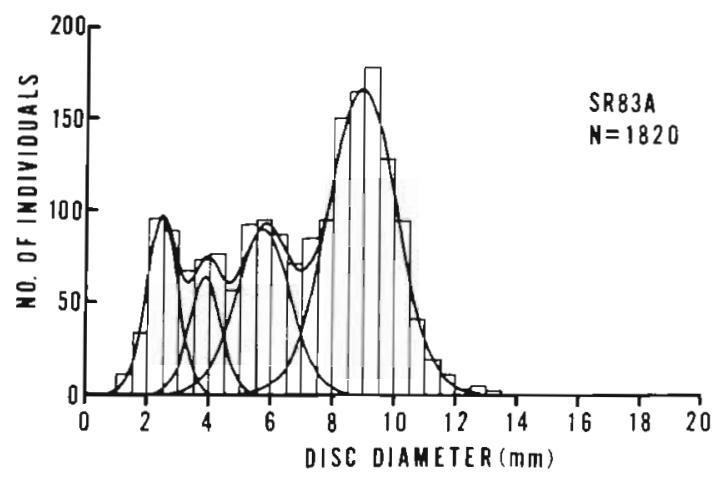

Fig. 2. Ophiura sarsij. Size-frequency distribution at depth about $250 \mathrm{~m}$ off Otsuchi on 10 March 1989 (Stn SR83A). Histogram denotes observed frequency. Curves represent 4 Gaussian component distributions and their summed frequency fitted by numerical analysis. The population was dominated by large individuals the sample of Stn SR83A with lines representing 4 component normal distributions and summed frequencies of these 4 components, fitted to the observed frequency. The right-hand frequencies were numerically dominated by large individuals with a mode at about $9.0 \mathrm{~mm}$, and smaller individuals are less numerous with 3 modes at about 2.5, 3.9 and $5.7 \mathrm{~mm}$.

\section{Size structures in a time-series sample off $\bar{O}$ tsuchi}

Progressive changes in the size-frequency distributions of Ophiura sarsii were followed at a depth of about $250 \mathrm{~m}$ off $\bar{O}$ tsuchi, from 7 consecutive samples collected at 1 to 5 mo intervals from May 1987 to March 1989 (Fig. 3). As the mesh size of the trawls was too large to collect newly settled postlarvae, settlement was not detected. Polymodal distribution of the size frequencies suggested discrete recruitment into the population of $O$. Sarsii in this site. Modes of very small individuals (less than $2 \mathrm{~mm}$ ) were found in the samples

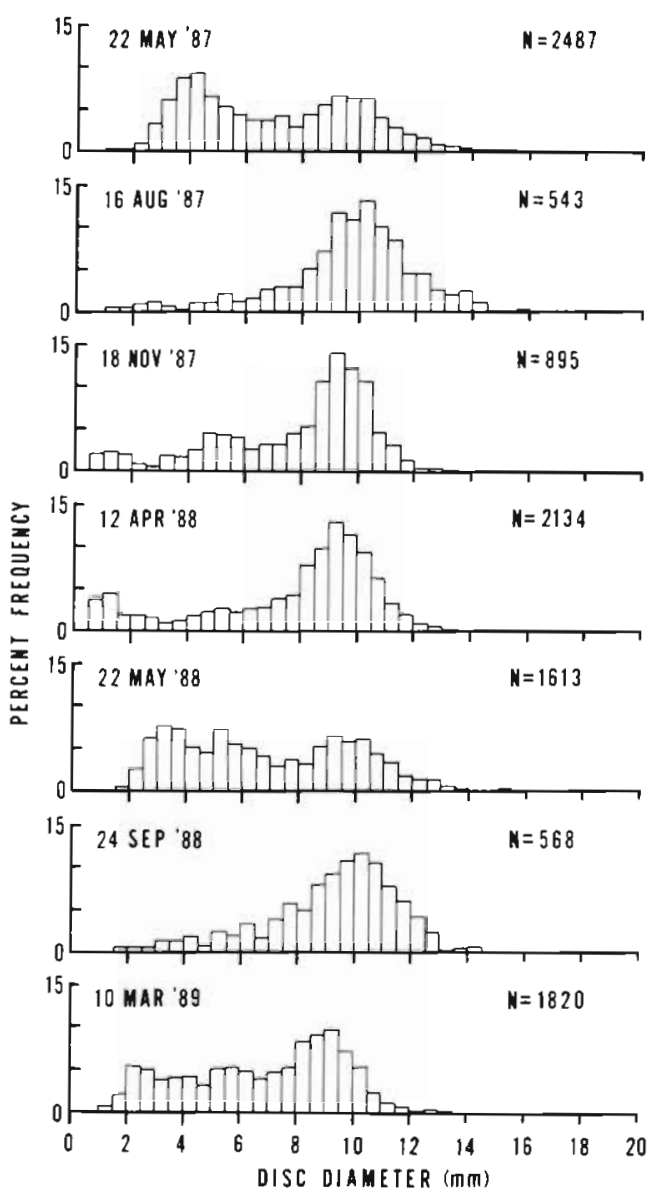

Fig. 3. Ophiura sarsii. Size-frequency distributions in timeseries samples at depth of about $250 \mathrm{~m}$ off Otsuchi from May 1987 to March 1989 
of November 1987 and April 1988. This is, at least partly, because these samples were collected by the net with $1 \mathrm{~mm}$ mesh opening while all other samples were collected by the net with $5 \mathrm{~mm}$ mesh opening. The smallest (about $1 \mathrm{~mm}$ ) individuals found in November 1987 and April 1988 were presumably the 0 -yr class which settled as post larvae around the beginning of 1987 and 1988, respectively.

Assuming that each size frequency was made up of 3 to 5 Gaussian distributions and taking connections between the consecutive size frequencies into consideration, the parameters of the component normal distributions (size, mean and standard deviation) were measured both by eye-fitting and by numerical analysis (Fig. 4; see also Fig. 2 as an example of the results of extracted components). A distinct mode of large individuals was always recognized at a disc diameter of 9 to $10 \mathrm{~mm}$ in each of the size-frequency distributions. The proportion of the component of large individuals was $0.62 \pm 0.16$ (mean $\pm \mathrm{SD}$ ) over the 7 samples, i.e. the component was formed by more than half the individuals of the population. Some periodicities were recognized in the size structure. Small individuals (2 to $6 \mathrm{~mm}$ ) were relatively abundant in the spring samples of May 1987, May 1988 and March 1989, indicating an annual peak of recruitment into the smallest size fractions ( 2 to $4 \mathrm{~mm}$ ) from March to May at this depth off Otsuchi. Fig. 4 does not provide accurate growth estimates, because we have no other independent information on age, and it was difficult to divide clearly each frequency distribution into year classes, and to track the intermediate modes through consecutive samples. A growth of about $2.5 \mathrm{~mm}$ in disc diameter during a year was interpreted for small individuals. For sizes greater than about $8 \mathrm{~mm}$ in disc diameter, the year class merged into a numerically dominant mode of

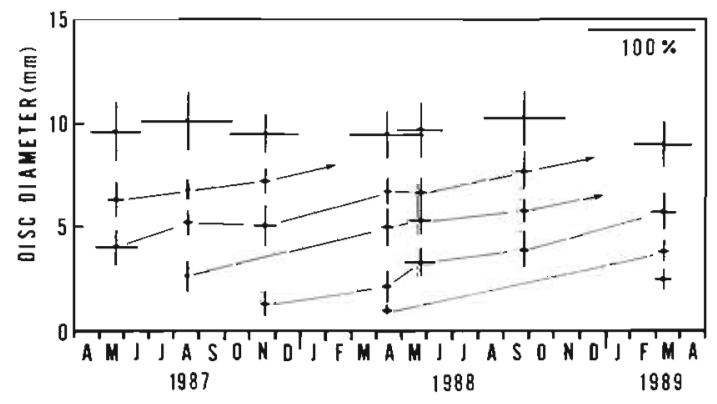

Fig. 4. Ophiura sarsii. Progressive changes of modes in sizefrequency distributions at depth about $250 \mathrm{~m}$ off $\bar{O}$ tsuchi. Parameters of components of Gaussian mixtures were fitted to observed frequencies in the samples (see Fig. 3). Vertical lines indicate $\pm 1 \mathrm{SD}$ around mean of each component and horizontal ones denote proportion of the component. Component means identified as putative year classes are linked by lines in consecutive samples the largest individuals. Since the size of this mode was considerably greater than those formed by smaller individuals, the mode of large individuals may result from the accumulation of many year classes. Differences between 2 successive modes within a sample were about $2 \mathrm{~mm}$, and this may correspond to growth for $1 \mathrm{yr}$. This was approximately equivalent to the estimate from the shift of the intermediate mode.

\section{Depth-related gradient in size structure along a bathymetric transect off $\bar{O}$ tsuchi}

The pattern of the density of epibenthic ophiuroids including Ophiura sarsii and others was examined along the depth gradient in the area off $\bar{O}$ tsuchi (Fig.5). Epibenthic ophiuroids were very sparse at depths less than $200 \mathrm{~m}$; their density increased abruptly between 200 and $600 \mathrm{~m}$. It reached a maximum value (more than $1000 \mathrm{~m}^{-2}$ ) around $350 \mathrm{~m}$ depth and decreased gradually at greater depths. No, or only few, individuals of infaunal ophiuroids were collected at these depths.

Species composition of the dense beds of epibenthic ophiuroids also changed along the depth gradient off Otsuchi (Fig. 5). Shallower than $300 \mathrm{~m}$, samples collected by trawling were comprised mostly of Ophiura sarsii $(86 \pm 12 \%$ of total number of ophiuroids; mean $\pm \mathrm{SD}, \mathrm{N}=6$ ). Other ophiuroid species were also found at intermediate depths $(300$ to $400 \mathrm{~m})$. The smaller congener $O$. leptoctenia showed the highest density making up $88 \pm 6 \%(\mathrm{~N}=5)$ of epibenthic ophiuroids. In the deepest part of the dense bed (more than about $400 \mathrm{~m}$ depth), 4 dominant ophiuroid species coexisted. $O$. sarsii $(26 \pm 14 \%$ of total ophiuroids, $N=8$ ) and $O$. leptoctenia (68 $\pm 13 \%$, $\mathrm{N}=8$ ) were found together with the 2 less abundant

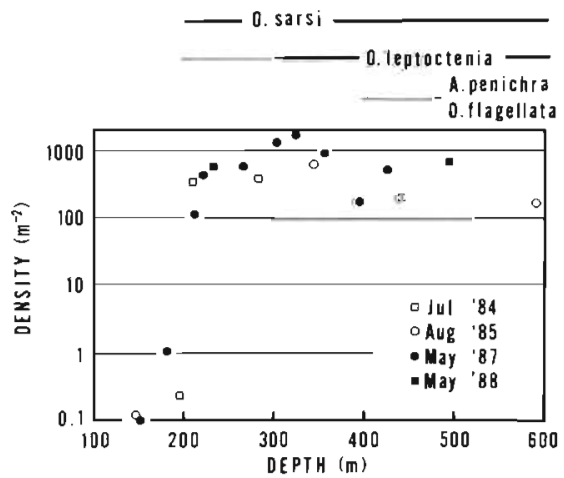

Fig. 5. Density of ophiuroids and bathymetric zonation of 4 dominant ophiuroids along the depth gradient off Otsuchi. Density estimate includes all epibenthic ophiuroids. Density increased abruptly at depth about $200 \mathrm{~m}$. Maximum value reached about $1800 \mathrm{~m}^{-2}$ at depth $324 \mathrm{~m}$. Outline of bathymetrical ranges of 4 dominant ophiuroids is shown in the upper part 


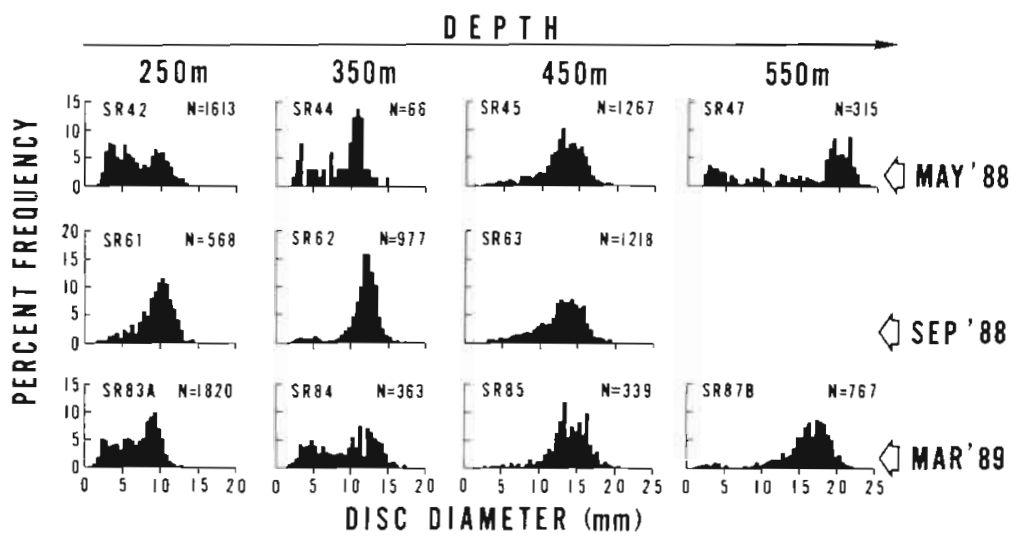

Fig. 6. Ophiura sarsu. Size-frequency distributions along the depth gradient off Otsuchi. Larger individuals were found at greater depths. Seasonal variations were larger in shallower depths species O. flagellata and Amphiophiura penichra. The total density was lower than that in intermediate depths. The density of $O$. sarsii tended to decrease toward greater depth

Some differences in the size structures of Ophiura sarsii were recognized among samples from various depths along the transect off $\bar{O}$ tsuchi (Fig. 6). With increasing depth, larger individuals were found. The relationships between depth and the size structures of $O$. sarsii are shown in Fig. 7 . A trend of increasing mean size with increasing depth was evident, and the maximum size increased greatly at a depth of about $400 \mathrm{~m}$. The modal size of the large individuals peak also shifted to the right with increasing depth. These 3 values (i.e. mean size, maximum size, adult mode) increased significantly with depth $(p<0.001)$. The skewness of the size distribution was negatively correlated with depth (Fig. $8 ; \mathrm{p}<0.02$ ); i.e. the deeper population had a larger proportion of large individuals and included relatively fewer small individuals. At shallower depths, seasonal variation of size structures were greater (Fig.6), consequently showing a wide range of skewness (Fig. 8). Particularly at a depth about $350 \mathrm{~m}$, where $O$. leptoctenia was extremely abundant, the skewness varied strongly and showed a minimum value in summer.

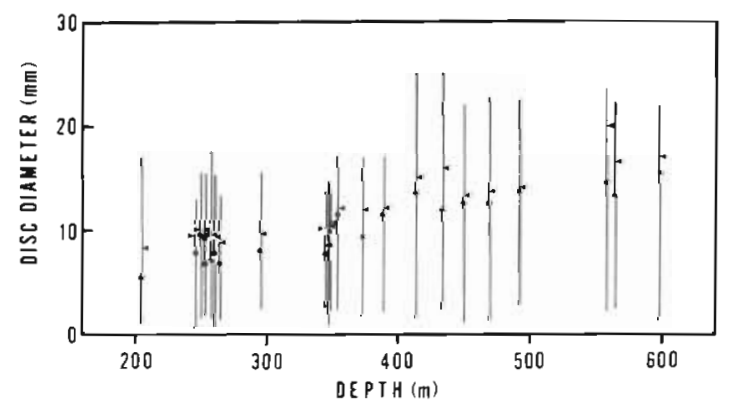

Fig. 7 Ophiura sarsii. Relationship between size structures and depth in the area off Otsuchi. (0) Mean values of size; vertical bars: ranges (minimum and maximum values) of size; (-) mode of large individuals. Mean size, maximum size and mode of adults increased with depth

\section{Regional comparison of dense beds}

Samples of Ophiura sarsii were collected at 7 isobathic stations (about $250 \mathrm{~m}$ ) off the Pacific coast of northern Japan and in the Japan Sea for a comparative examination of size structure (Fig. 9, Table 2). O. sarsii was a dominant species in these areas. At these stations, except Stn 8 off Akita, no or few individuals of infaunal ophiuroids were found, and more than $95 \%$ of total ophiuroid individuals were $O$. sarsii. At Stn 8 , the ophiuroids comprised $O$. sarsii $(77 \%), O$. leptoctenia $(6 \%)$ and infaunal amphiurids $(18 \%) ; 94 \%$ of epibenthic ophiuroids consisted of $O$. sarsii. Several individuals of Asteronyx loveni, an epizoic species, were collected at Stn 7 off Hachinohe. The density of epibenthic ophiuroids, which can be thought to be approximately equivalent to the density of $O$. sarsii, varied from locality to locality. Values were smaller in the Japan Sea (Stn 8 off Akita, Stn 5-4 off Wakasa Bay, Stn 13 off Hinomisaki) than on the Pacific side (Stn 7 off

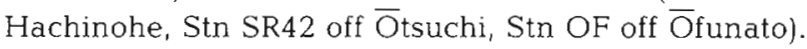

Most of the populations of Ophiura sarsii were dominated by large individuals, but a peculiar size structure was observed at the station off Hachinohe (Stn 7) in October 1988, with a peak of young sizes of about $2.5 \mathrm{~mm}$ disc diameter and a widely dispersed adult component



Fig. 8. Ophiura sarsii. Relationship between skewness of size distributions and depth in the area of Otsuchi. Skewness was larger when recruitment was strong. Skewness tends to decrease with increasing depth, and the minimum value was observed at depth about $350 \mathrm{~m}$ 
Fig. 9. Ophiura sarsii. Size-frequency distribution in various locations at depth about $250 \mathrm{~m}$ around Japan. $(\bullet$ Quantitative and (o) qualitative sampling stations. Other published records of dense beds of $O$. sarsii are also indicated, representing (₫) quantitative and ( $\Delta$ ) qualitative data (after Yamamoto 1950, Suzuki 1979, Hashimoto \& Hotta 1985). Numerals and symbols adjacent to the circles represent population density $\left(\mathrm{m}^{-2}\right)$ and locality (K: off Kiritappu, M: Mutsu Bay, Y: off Yamagata, T: Toyama Bay), respectively

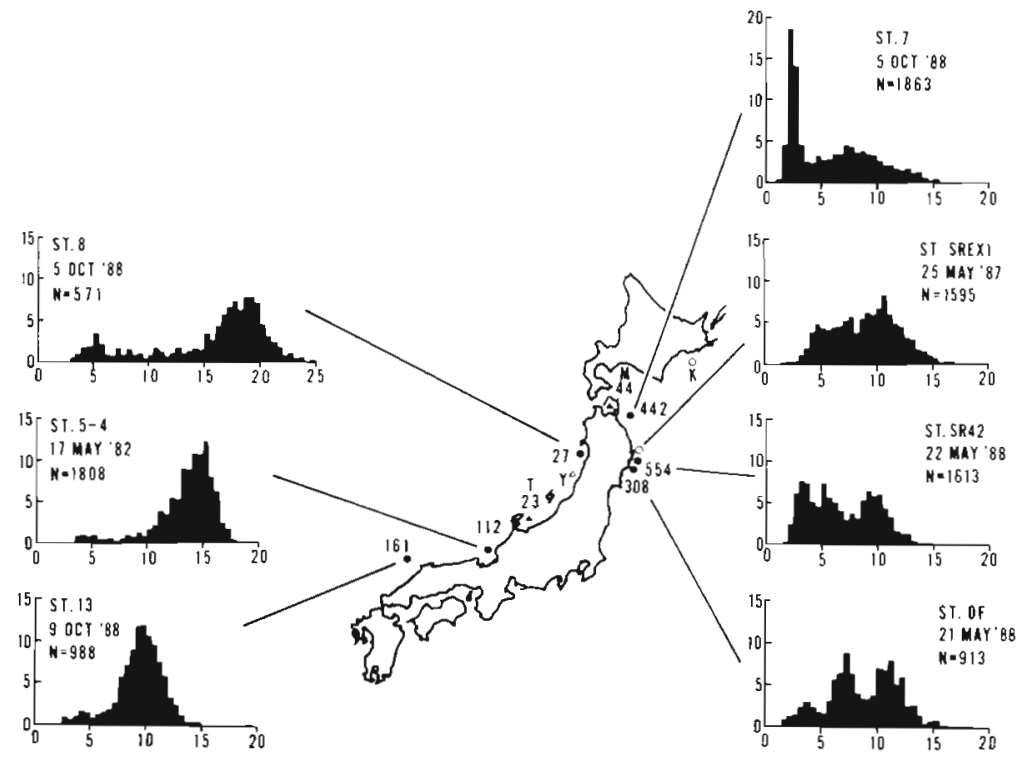

(mode $=$ ca $7.5 \mathrm{~mm}$ ). The body size of $O$. sarsii in the Japan Sea was larger than that in the Pacific samples; in particular off Akita ( $\operatorname{Stn} 8$ ), the population consisted of very large individuals (mode $=17$ to $19 \mathrm{~mm}$ ) (Fig. 9). On the Pacific coast, the largest size (25 $\mathrm{mm}$ maximum disc diameter) was found off Kiritappu (Fig. 9, Table 2).

The size distribution of Ophiura sarsii at each station is plotted against its population density in Fig. 10. Mean size $(p<0.01)$, maximum size $(p<0.01)$ and adult mode $(\mathrm{p}<0.02)$ were inversely correlated to density. As the population density increased, skewness increased towards a positive value $(p<0.02)$. Biomass was not significantly $(p>0.05)$ correlated to density. Although the density varied widely among the 8 isobathic stations ( $\mathrm{CV} 62 \%$ ), the biomass remained relatively constant (CV 28\%) (Fig. 11).

\section{DISCUSSION}

Dense beds of Ophiura sarsii are widely distributed in the northern hemisphere (Djakonov 1954, Astrahant-

Table 2. Ophiura sarsii. Distribution and density around Japan

\begin{tabular}{|c|c|c|c|c|}
\hline Area & Depth $(\mathrm{m})$ & Methods ${ }^{a}$ & Remarks & Reference \\
\hline \multicolumn{5}{|l|}{$\underline{\text { Pacific coast }}$} \\
\hline off Kiritappu & $100-479$ & $\mathrm{BT}(8)$ & $\begin{array}{l}\text { Abundant (150-300 } \mathrm{m} \text { ), max- } \\
\text { imum diameter } 25 \mathrm{~mm}\end{array}$ & Present study ${ }^{\mathrm{b}}$ \\
\hline off Hachinohe & $225-248$ & $\operatorname{BT}(1), \operatorname{UP}(1)$ & $442 \mathrm{~m}^{-2}(\mathrm{St} .7)$ & Present study \\
\hline off Miyako & $253-319$ & $\mathrm{DR}(2)$ & Abundant (Stn SREX1) & Present study \\
\hline off Ōtsuchi & $199-623$ & UP (19), BT (31) & $\begin{array}{l}554 \mathrm{~m}^{-2} \text { (Stn SR } 42,233 \mathrm{~m} \text { ), see } \\
\text { text for details }\end{array}$ & Present study \\
\hline off $\bar{O}$ funato & $250-259$ & $\mathrm{BT}(1), \operatorname{UP}(1)$ & $308 \mathrm{~m}^{-2}(\operatorname{Stn}$ OF $)$ & Present study \\
\hline Mutsu Bay & & $\mathrm{EB}(7)$ & $44 \mathrm{~m}^{-2}, 22 \%$ of benthic community & Yamamoto (1950) \\
\hline \multicolumn{5}{|l|}{ Japan sea } \\
\hline off Akita & $250-260$ & $\mathrm{BT}(1), \mathrm{UP}(1)$ & $27 \mathrm{~m}^{-2}(\operatorname{Stn} 8)$ & Present study \\
\hline off Yamagata & $152-400$ & CT & $\begin{array}{l}\text { Abundant (270-400 m), diameter } \\
23-25 \mathrm{~mm}\end{array}$ & Suzuki (1979) \\
\hline Toyama Bay & $220-740$ & SO (3) & $23 \mathrm{~m}^{-2}$ & Hashimoto \& Hotta (1985) \\
\hline off Wakasa Bay & $201-547$ & $\mathrm{BT}(3), \mathrm{UP}(3)$ & $112 \mathrm{~m}^{-2}(\operatorname{Stn} 5-4,278 \mathrm{~m})$ & Present study \\
\hline off Hinomisaki & $245-250$ & $\mathrm{BT}(1), \mathrm{UP}(1)$ & $161 \mathrm{~m}^{-2}(\operatorname{Stn} 13)$ & Present study \\
\hline \multicolumn{5}{|c|}{$\begin{array}{l}\text { abbreviations for methods: BT, beam trawl; UP, underwater photography; DR biological dredge; EB, Ekman-Birge grab; CT, } \\
\text { commercial trawl; SO, submersible observations. In parentheses: number of samples obtained } \\
\text { b These samples were collected by Sigsby-Agassiz beam trawl of } 2 \mathrm{~m} \text { span in July } 1983 \text {. Eight stations were located south of } \\
\text { Kiritappu, on the Pacific coast of Hokkaido (see Fig. } 9 \text { for the location). Samples were possibly biased in terms of size, and the } \\
\text { size frequency was not presented in this study }\end{array}$} \\
\hline
\end{tabular}




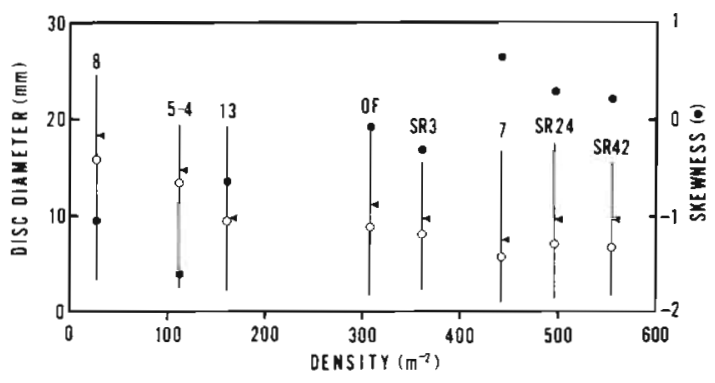

Fig. 10. Ophiura sarsii. Relationship between size structures and population density in various localities around Japan. (0) Mean value; vertical bar: range of size; ( $\downarrow$ ) mean size of largesized adult mode $e_{i}(\bullet)$ skewness. Station number is indicated above bars. Mean size, maximum size and mode of adults were negatively correlated with density, and skewness was positively correlated with it. Note that 3 stations off $\bar{O}$ tsuchi (SR3, SR24, SR42) are included

seff \& Alton 1965, Haedrich et al. 1980). The present study and several previous records (Clark 1911, Yamamoto 1950, Suzuki 1979, Hashimoto \& Hotta 1985) indicate that the seas surrounding the northern part of Japan are blanketed, probably without any great interruption, by dense beds of $O$. sarsii between depths of about 200 and $600 \mathrm{~m}$ (Fig. 9, Table 2).

These dense populations of Ophiura sarsii are dominated numerically by large adults. The mode of large individuals is made up of a stack of many year classes. Such a stacked mode of adult age classes was also reported for a deep-sea ophiuroid, Ophiomusium Iymani (Gage \& Tyler 1982a, c), and a shallow-water burrowing ophiuroid, Amphiura filiformis (O'Connor \& McGrath 1980, O'Connor et al. 1983), both species which may form dense beds. This type of size structure permits a high density to be stabilized over many years more easily than one dominated by small juveniles found in some shallow-water fissiparous ophiuroids; such asexual ophiuroids generally occur in more disturbed and transient habitats and their population densities vary strongly (Mladenov \& Emson 1988). The population densities of the former-type populations are less affected by variability in recruitment. Continuous occupation of the sea floor at high density may be necessary for maintaining the population of dense bedforming ophiuroids.

Recently, seasonal patterns in reproduction and growth were reported for deep-sea organisms in some areas (Tyler 1988). In the Rockall Trough (2200 to $2900 \mathrm{~m}$ deep), northeastern Atlantic, the size structures of some ophiuroids varied seasonally, showing seasonal recruitment; Ophiura ljungmani (Tyler \& Gage 1980, Gage \& Tyler 1981b, Gage 1985) and Ophiocten gracilis (Gage \& Tyler 1981a, 1982b) are known to reproduce seasonally, but Ophiomusium lymani (Gage \& Tyler 1982a) shows no seasonal reproduction and its

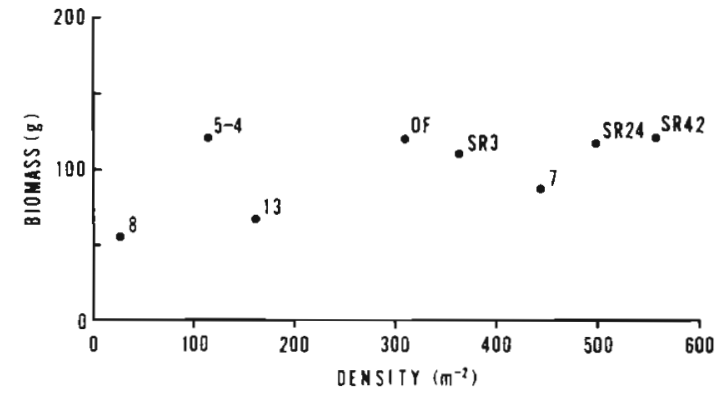

Fig. 11. Ophiura sarsii. Relationship between density and biomass. Circles are identified by station names. Compared with the wide range of density, the value of biomass is relatively constant

seasonal variation in recruitment was apparently caused by a seasonal cycle in postlarval survivorship. Likewise, in the upper bathyal zone off $\bar{O}$ tsuchi, seasonal variations were observed in the size structures of Ophiura sarsii and the recruitment into parent population has a peak in spring, although the patterns of reproduction and settlement have still not been clarified in this area. The degree of seasonal variation is lower at the deeper site (Figs. 6 and 8). As the proportion of the intermediate year class is less than $20 \%$ of the total population, and the population turnover rate of $O$. sarsii is low, clear estimation of growth and other demographic parameters needs other information about age (e.g. growth ring, if present).

Local heterogeneity of size structures might be caused by local differences in various ecological processes: reproduction, recruitment, growth, mortality, interspecific competition and predation. In the present study areas, negative correlation between size and density was observed for Ophiura sarsii (Fig. 10), and this density dependency suggests the body size was affected more by intraspecific factors than by interactions with other species. Such density-dependent size regulation has been commonly found for echinoderms (Lawrence \& Lane 1982) and high density may suppress the growth of $O$. sarsii, probably through limitation of space or food. Extremely high density was observed off Otsuchi, where comparison between the inter-individual distance and the arm length suggests that the abundance of the ophiuroid is nearly saturated values in terms of space (Fujita \& Ohta 1989). The density effect results in a relatively constant biomass at the various isobathic localities (Fig. 11). Carrying capacity of $O$. sarsii appears regulated in terms of biomass (not density), and space (or accordingly food input) may limit the sustainable biomass for ophiuroids at least in the most abundant area off $\bar{O}$ tsuchi. The regional comparison of Ophiomusium lymani indicates that maximum size depends on the population density limited by food (Gage 1982). A density-dependent feedback is thought to result in lower survivorship of 
adults at higher densities for O. lymani. Local differences were also recognized in the recruitment patterns of 0 . sarsii. At $\operatorname{Stn} 7$, the conspicuous peak of small individuals and relatively abundant medium-sized individuals suggest intense reacruitment occurred at least in October 1988. The environment also seems unusual; bottom temperature was higher than at any other stations studied, and Asteronyx loveni was found although mainly distributed in the deeper zone (Fujita \& Ohta 1988).

Ophiura sarsii is reported to reach a maximum size of $40 \mathrm{~mm}$ disc diameter (Djakonov 1954) which is much larger than that in the seas around Japan, the southern limit of geographical distribution in the NW Pacific. A latitudinal cline of body size might be shown by comparison of samples from a world-wide range. Correspondingly, within the present study area, northern samples (off Kiritappu, off Akita) were larger than southern samples (off Sanriku, off Hinomisaki) both on the Pacific coast and in the Japan Sea (Table 2).

Off Otsuchi, dense beds including Ophiura sarsii were found between depths of 200 and about $600 \mathrm{~m}$. The shallowest edge of the dense bed was sharp at a depth about $200 \mathrm{~m}$, where the density changed abruptly (Fig. 5). This demarcation seems to be determined by physical environmental factors such as temperature, hydrographic regime or food input, although no positive evidence has yet been found. Within the dense bed, as the depth increases, the size of $O$. sarsii increases (Fig. 7), seasonal variations in size structures decreases (Fig. 6), and skewness of size structure tends to decrease (Fig. 8). The large seasonal variations and high skewness suggest relatively strong recruitment in the shallowest part (about 200 to $300 \mathrm{~m}$ ) which is occupied almost exclusively by $O$. sarsii. On the other hand, small individuals are scarcely found in the deeper part $(>400 \mathrm{~m})$, and recruitment is poor and/or sporadic. This may result from the pattern of settlement, or high mortality of post-settled juveniles may prevent newly settled individuals from growing to the size collected by the trawls. At depths greater than $300 \mathrm{~m}$, Ophiura leptoctenia is very abundant and its size is about $5 \mathrm{~mm}$ disc diameter. It seems possible that the lack of small individuals of $O$. sarsii is caused by high mortality of junveniles due to interspecific competition with $O$. leptoctenia. In the deeper zone $(>400 \mathrm{~m})$, many species coexist, and the density of ophiuroids is relatively low. The low density probably allows greater size, and large individuals of $O$. sarsii could be distributed where inter-specific competition is strong.

Thus, within the dense bed off Otsuchi, Ophiura sarsii forms 2 different zones in size structure. The first zone lies in the shallower part of the bed where $O$. sarsii occurs on its own. The zone is favorable for recruitment because of lack of interspecific competition. However, the high density depresses maximum body size in this zone. In the second zone, at greater depths, recruitment is poor but maximum size was greater and the large size could confer a competitive advantage over other ophiuroid species occupying the same niche. These depth-related gradients in size structure show a basically similar pattern to local differences in size structure and density (Figs.9 and 10). Towards the south and shallower depth, possibly the distributional limit of the species, body size was smaller. Our data for $O$. sarsii accords with Ebert's (1983) idea that recruitment should be greatest and life should be shortest at the shallowest portion of the species range (shown in Ophiura ljungmani). Gage \& Tyler (1982b) reported, however, that postlarval survivorship of $O$. ljungmani was not high at a deep site, in contradiction to Ebert's suggestion.

The right-hand dominated size structure contributes to persistence of the dense beds of Ophiura sarsii through the continuous maintenance of high and steady population density. The dense beds shows local variations from high-density, small-size, strong-recruitment to low-density, large-size, poor-recruitment. These 2 types seem to play a role in persistence of the dense beds in a compensatory manner.

Acknowledgements. We are indebted to Dr John D. Gage of the Scottish Marine Biological Station for kindly reading the manuscript and offering many useful suggestions. Dis Ken-ichi Numachi and Munehiko Iwata of the former staff of the Otsuchi Marine Center made the facilities of RV 'Yayoi' available to us. We also thank the staff and crew members of the RV 'Tansei Maru', RV 'Hakuho Maru' and RV 'Yayoi', the Ocean Research Institute, University of Tokyo, for their help in sampling. Thanks are extended to 3 anonymous reviewers for improving this manuscript.

\section{LITERATURE CITED}

Akamine, T (1982). A BASIC program to analyse the polymodal frequency distribution into normal distributions. Bull. Jap. Sea Reg. Fish. Res. Lab. 33: 163-166 (in Japanese; English abstract)

Aronson, R. B., Harms, C. A. (1985). Ohiuroids in a Bahamian saltwater lake: the ecology of a Paleozoic-like community. Ecology 66: 1472-1483

Aronson, R. B., Sues, H.-D. (1987). The paleoecological significance of an anachronistic community. In: Kerfoot, W. C., Sih, A. (eds.) Predation: direct and indirect impacts on aquatic communities. University Press of New England, Hanover, p. 355-366

Astrahantseff, S., Alton, M. S. (1965). Bathymetric distribution of brittlestars (Ophiuroidea) collected off the northern Oregon coast. J. Fish. Res. Bd Can. 22: 1407-1424

Clark, H. L. (1911). North Pacific ophiurans in the collection of the United States National Museum. Bull. Smithson. Inst., U. S. Natn. Mus. 75: 1-302

Djakonov, A. M. (1954). Ophiuroids of the USSR seas. The Zoological Institute of the Academy Science of the USSR, 
Moskow (translated from Russian by Israel Program for scientific translations)

Ebert, T A (1983). Recruitment in echinoderms. In: Jangoux, M., Lawrence, J. M. (eds.) Echinoderm studies 1. Balkema, Rotterdam, p. 169-203

Fujita, T. (1989). Ecological study on the deep-sea echinoderms through photographic observations in the bathyal zone around Japan. Doctoral dissertation, University of Tokyo

Fujita, T., Ohta, S. (1988). Photographic observations of the life style of a deep-sea ophiuroid Asteronyx Ioveni (Echinodermata). Deep-Sea Res. 35: 2029-2043

Fujita, T., Ohta, S. (1989). Spatial structure within a dense bed of the brittle star Ophiura sarsii (Ophiuroidea: Echinodermata) in the bathyal zone off Otsuchi, northeastern Japan. J. Oceanogr. Soc. Jap. 45: 289-300

Gage, J. D. (1982). Age structure in populations of the deepsea brittle star Ophiomusium lymani: a regional comparison. Deep-Sea Res. 29: 1565-1586

Gage, J. D. (1985). The analysis of population dynamics in deep-sea benthos. In: Gibbs, P. E. (ed.) Proc. 19th Europ. Mar. Biol. Symp. Cambridge University Press, Cambridge, p. 201-212

Gage, J. D., Tyler, P. A. (1981a). Non-viable seasonal settlement of larvae of the upper bathyal brittle star Ophiocten gracilis in the Rockall Trough Abyssal. Mar. Biol. 64: 153-161

Gage, J. D., Tyler, P. A. (1981b). Re-appraisal of age composition, growth and survivorship of the deep-sea brittle star Ophiura ljungmani from size structure in a sample time series from the Rockall Trough. Mar. Biol 64: 163-172

Gage, J. D., Tyler, P. A. (1982a). Growth and reproduction of the deep-sea brittlestar Ophiomusium Iymani Wyville Thomson. Oceanol. Acta 5: 73-83

Gage, J. D., Tyler, P. A. (1982b). Depth-related gradients in size structure and the bathymetric zonation of deep-sea brittle stars. Mar. Biol. 71: 299-308

Gage, J. D., Tyler, P. A. (1982c). Growth strategies in deep-sea ophiuroids. In: Lawrence, J. M. (ed.) Proc. International Echinoderm Conference. Balkema, Rotterdam, p. 305-311

Haedrich, R. L., Rowe, G. T., Polloni, P. T. (1980). The megabenthic fauna in the deep sea south of New England, USA. Mar. Biol. 57: 165-179

Hashimoto, J., Hotta $H,(1985)$. An attempt of density estimation of megalo-epibenthos by the deep towed TV system and the deep sea research submersible 'SHINKAI 2000' JAMSTECTR. Deep-Sea Res. 1985: 23-35 (in Japanese, English abstract)

This article was presented by Dr J. D. Gage, Oban, Scotland
Kojima, S., Ohta, S. (1989). Patterns of bottom environments and macrobenthos communities along the depth gradient in the bathyal zone off Sanriku, northwestern Pacific. J. Oceanogr. Soc. Jap. 45: 95-105

Lawrence, J. M., Lane, J. M. (1982). The utilization of nutrients by post-metamorphic echinoderms. In: Jangoux, M., Lawrence, J. M. (eds.) Echinoderm nutrition. Balkema, Rotterdam, p. 331-371

Madenov, P. V., Emson, R. H. (1988). Density, size structure and reproductive characteristics of fissiparous brittle stars in algae and sponges: evidence for interpopulational variation in levels of sexual and asexual reproduction. Mar. Ecol. Prog. Ser. 42: 181-194

Muus, K. (1981). Density and growth of juvenile Amphiura filiformis (Ophiuroidea) in the Øresund. Ophelia 20: 153-168

O'Connor, B., Bowmer, T., Grehan, A. (1983). Long-term assessment of the population dynamics of Amphiura filiformis (Echinodermata: Ophiuroidea) in Galway Bay (west coast of Ireland). Mar. Biol. 75: 279-286

O'Connor, B., McGrath, D. (1980). The population dynamics of Amphiura filiformis (O. F. Müller) in Galway Bay, west coast of Ireland. In: Jangoux, M. (ed.) Echinoderms: present and past. Balkema, Rotterdam, p. 219-222

Ohta, S. (1976). A precise and continuous monitoring system of the distance between the near-bottom instruments and the sea floor. J. Oceanogr. Soc. Jap. 32: 65-73

Ohta, S. (1983). Photographic census of large-sized benthic organisms in the bathyal zone of Suruga Bay, central Japan. Bull. Ocean Res. Inst. Univ. Tokyo 15: 1-244

Sokal, R. R., Rohlf, F. J. (1981). Biometry, 2nd edn. W. H Freeman and Co., New York

Suzuki, S. (1979). Marine invertebrate animals of Yamagata Prefecture. Tamakibi-Kai, Yamagata (in Japanese)

Tyler, P. A. (1988). Seasonality in the deep sea. Oceanogr. mar. Biol. A. Rev. 26: 227-258

Tyler, P. A., Gage, J. D. (1980). Reproduction and growth of the deep-sea brittlestar Ophiura ljungmani (Lyman) Oceanol. Acta 3: 177-185

Warner, G. F. (1971). On the ecology of a dense bed of the brittle-star Ophiothrix fragilis. J. mar. biol. Ass. U. K. 51: $267-282$

Wilson, J. B., Holme, N. A., Barrett, R. L. (1977). Population dispersal in the brittle-star Ophiocomina nigra (Abildgaard) (Echinodermata: Ophiuroidea). J. mar. biol. Ass. U. K. 57: 405-439

Yamamoto, G. (1950). Benthic communities in Mutsu Bay. Sci. Rep. Tohoku Univ. 4th Ser (Biol.) 18: 482-487

Manuscript first received: August 29, 1989

Revised version accepted: April 6, 1990 